\title{
Imatinib Mesylate
}

National Cancer Institute

\section{Source}

National Cancer Institute. Imatinib Mesylate. NCI Thesaurus. Code C1687.

The mesylate salt of imatinib, a tyrosine kinase inhibitor with antineoplastic activity.

Imatinib binds to an intracellular pocket located within tyrosine kinases (TK), thereby inhibiting ATP binding and preventing phosphorylation and the subsequent activation of growth receptors and their downstream signal transduction pathways. This agent inhibits TK encoded by the bcr-abl oncogene as well as receptor T Ks encoded by the c-kit and platelet-derived growth factor receptor (PDGFR) oncogenes. Inhibition of the bcr-abl TK results in decreased proliferation and enhanced apoptosis in malignant cells of Philadelphia-positive $(\mathrm{Ph}+)$ hematological malignancies such as $\mathrm{CML}$ and $\mathrm{ALL}$; effects on c-kit TK activity inhibit mast-cell and cellular proliferation in those diseases overexpressing c-kit, such as mastocytosis and gastrointestinal stromal tumor (GIST). 